\title{
THE RUWENZORI RANGE
}

THE Ruwenzori Range, Uganda, was visited in January $195^{1}$ by a party organized by the writer. The object of the party was chiefly geological reconnaissance but several glaciers were visited; beacons placed the previous year by I. R. Menzies were observed and some additional beacons were set up. A number of glaciological observations was made and will form a basis for further work. Ski were used on the Stanley Plateau for the first time.

A project for a thorough scientific exploration of the Ruwenzori Range is being financed by the Uganda Government and has received grants from the Royal Society, the Geological Society, the Royal Geographical Society and Leeds University. The British Museum has also promised support. The exploration is being organized by Professor W. Q. Kennedy, F.R.S., of Leeds University, in conjunction with the writer on behalf of the Geological Survey of Uganda. A party of geologists made a preliminary survey of Ruwenzori during July, August and September I95I. A larger expedition is being planned for the summer of 1952 , and it is hoped to include a glaciologist.*

Geological Survey of Uganda,

R. B. MCCONNELL

Entebbe, Uganda

${ }_{5}$ September $195 \mathrm{I}$

\section{MEETING OF THE INTERNATIONAL COMMISSION ON SNOW AND ICE, BRUSSELS, I 95 I}

THE International Commission on Snow and Ice, as it is now called, is one of the three Commissions of the International Association of Hydrology which in its turn is one of the seven Associations adhering to the International Union of Geodesy and Geophysics. The two sister Commissions of the Association are those of Surface and Underground Waters. In addition, the Association sponsors certain Committees entrusted with specific tasks.

The other six Associations of the International Union are (I) Geodesy, (2) Seismology, (3) Meteorology, (4) Terrestial Magnetism and Electricity, (5) Oceanography and (6) Vulcanology. The I.U.G.G. is itself one of nine Unions functioning under the International Council of Scientific Unions through which there is also connexion with U.N.E.S.C.O. The other eight Unions are (I) Astronomy, (2) Chemistry, (3) Radio Science, (4) Physics, (5) Geography, (6) Biology, (7) Crystallography and (8) Theoretical and Applied Mechanics.

The Congress of the I.U.G.G. and its constituent bodies was held at Brussels from 20 August to I September I951. Some thirty-six representative countries were listed and the names of about 670 delegates and guest representatives were registered. The corresponding number of delegates at Oslo, where in 1948 the first post-war meeting was held, was about $35^{\circ}$. At both meetings many delegates were accompanied by their ladies. Accommodation for meetings and the reading of papers was provided in the buildings of the University of Brussels.

A valuable innovation was an exhibition of scientific instruments held in one of the halls of the University at which the products of German firms stood out prominently. American, French and Swiss instrument makers provided the bulk of the remaining exhibits.

Twenty-six reports and papers were read and discussed at meetings of the Commission, a considerably smaller number than in 1948 . But thanks to the more selective treatment of papers

* Glaciological research on the Belgian Congo side of the range is also in preparation under M Jean de Heinzelin of Brussels, and it is to be hoped that correlation between the two expeditions may be arranged. Dr. McConnell's present address is Department of Geology, Oxford. $-E d$. 
by the authorities and the experience gained at Oslo, much more time was given to each paper, including adequate time for discussion; the usefulness and interest of the meeting increased greatly in consequence. In addition, six papers were read by title or presented in summary. It is understood to be the intention to publish all these in the Transactions of the Association, together with one or two contributions received too late for inclusion in the programme.

The extension of time allotted to papers raises a difficulty since this entails an overlap with the meetings of other Commissions within the Association. As a result people who may be interested, say, in both surface water and glaciers cannot attend papers which may be read simultaneously on the two subjects. The Congress can quite certainly not be lengthened for reasons of economy and of time. In the writer's opinion (and in that of many with whom he has spoken) some degree of solution would be reached if the various ceremonial meetings were dispensed with or were held in the evenings. For instance, two half-days were devoted at Brussels to two Plenary Sessions of the whole Union-one in officially welcoming the delegates with their ladies, and the other in bidding them farewell. By different arrangement of the general programme some two or three days more could be given to the reading of papers with a comparable reduction in overlapping.

The papers read before the Commission were, many of them, of a very high standard, and glaciology will profit by their early publication.

The Commission decided not to set any questions for the papers for 1954 as had formerly been the custom. This is to the good, since glaciological research has become so active of recent years and development of technique so rapid that its momentum would over-ride any tendency to guide work into rigid channels. Glaciologists will prefer to work out their own plans for research.

This does not mean that the Commission should not attempt any guidance at all. Clearly it must, and does, keep its finger on the pulse. In 1948 it passed a very timely resolution recommending that a system of snow cover classification should be devised. It appointed a Committee consisting of Messrs. V. J. Schaefer (U.S.A.), J. G. Klein (Canada) and M. de Quervain (Switzerland) to deal with this.* At the 195 I meeting of the Commission the last named produced the Committee's final report. This was further discussed and some alterations of detail were suggested. It is to be sent to the International Meteorological Organization for final confirmation that it is in accord with meteorological usage, after which it will be put into international circulation. $\uparrow$

It is hoped to strengthen the Commission for its 1954 meetings. Several noted glaciologists were not present. In particular there were none from Germany or Austria - countries which have contributed so much to glaciology in the past. No French glaciologist was present although a paper on the recent seismic soundings on the Greenland Ice Cap was read by a French expert on that subject. Nor was there anyone from Iceland. This is the more regrettable since glaciological associations have recently been formed in both these countries. An invitation to Professor U. Nakaya of Japan was sent but arrived too late for his attendance.

The detailed and complex work of the Commission was handled with great efficiency by its Honorary Secretary, Mr. P. D. Baird (Canada), and the Commission is fortunate in that he has been reappointed for the present triennium. Mr. G. Seligman (Great Britain) and Professor R. Haefeli (Switzerland) were elected as President and Vice-President respectively in place of H.E. Dr. H. W:son Ahlmann and Mr. J. M. Wordie. Dr. Ahlmann was unable to attend the meetings and Mr. Wordie presided in his place. The local arrangements were admirably carried out by Professor L. J. Tison of the University of Ghent, Honorary Secretary of the Association, and his three excellent assistants.

Io September 195 I

G. Seligman

* See fournal of Glaciology, Vol. r, No. 9, p. 5०9-10
$\dagger$ A further note on this subject appears elsewhere in this issue. 


\section{PAPERS READ BEFORE \\ THE INTERNATIONAL COMMISSIONON \\ S NOW A D I CE, I 95 I}

Symposium on the Distribution of Snow and Ice throughout the World. Held at the REQUEST OF U.N.E.S.C.O.

Influences affecting glacier extension in Northern Sweden

Sur l'évaporation de la couverture de neige dans les Alpes Suisses

Glacier fluctuation in north-western North America within the past six centuries

Recent researches on the distribution of snow and sea ice in the eastern Canadian Arctic

Meteorological situations in the South Polar regions and alimentation of the Antarctic Ice Cap

Climatology and glaciology of Peary Land, North Greenland

Method of nourishment of an ice cap in Baffin Island

Glaciers de l'Afrique Centrale

\section{Glacier Variations}

Rapport sur les variations de longueur des glaciers Européens de 1947 à $195^{\circ}$ Report on glacier variation in North America

\section{InTERnational Classification of SNOW}

Report of the Committee

\section{Glacier Physics}

Geschwindigkeitsverhältnisse und Verformungen in einem Eisstollen des

M. de Quervain

M. de Quervain

D. B. Lawrence *

F. K. Hare *

H. H. Lamb

B. Fristrup

P. D. Baird

J. de Heinzelin

P. L. Mercanton*

W. O. Field *

Switzerland

United States
Nouvelle contribution à l'étude du grain de glacier

vertical profile through a

Determination Zmuttgletschers

Research on the Greenland Ice Cap

The physics of deglaciation in central Baffin Island

M. Perutz and

J. Gerrard

R. Haefeli and

P. Kasser

J. Martin

W. H. Ward

Melt water behavior in firn on upper Seward Glacier, St. Elias Mountains, Canada

The investigation of a possible method of cirque erosion
A. Renaud *
R. P. Sharp *

Miss J. M. Clark
Sweden

Switzerland

United States

Canada

Great Britain

Denmark

Canada

Belgium

\section{SNow Cover}

Summary of Canadian snow survey for 1946-1949

Snow investigations in Norway typique des Alpes Or

\section{VARIOUS}

Relation entre la température et la quantité d'eau de fonte de la couverture de neige et détermination indirecte des précipitations solides au moyen de cette relation

A possible mechanism of accumulation on the Quaternary Scandinavian ice cap

Transport of solid water matters in glacier currents $\ddagger$

Prévisions d'apports pendant la période de fusion des reserves nivales $\ddagger$

\section{Presented in Summary}

Sonde électrothermique pour le sondage des glaciers

Feasibility of snow survey in the Himalayas

India
Relationship between snow accumulation and river discharges in India

Contribution of snow to flood flow in Indian rivers

Étude de la neige et des avalanches
Maps of snow accumulation; a meteorological aid to hydrology

Des rapports entre les précipitations neigeuses et les débits d'un cours d'eau

Influence of snow accumulation in the Himalayas on the subsequent rainfall in
A. Jakhelln

D. C. Pearce and

L. W. Gold *

H. Klaeboe

D. Tonini

Th. Zingg *

T. Bergeron

H. Klaeboe

-. Ferry and

-. Lugiez

-. Remenieras and

. Terrier*

R. D. Dhir*

S. K. Pramanik and

K. N. Rao *

S. K. Pramanik and

K. N. Rao*

S. K. Pramanik and

K. N. Rao *

C. Sulzlee *
Switzerland

Switzerland

Great Britain

Switzerland

France

Great Britain

United States

Great Britain

Norway

Canada

Norway

Italy

Switzerland

Sweden

Norway

France

\section{France}

India

India

India

India

France

* Read in absentia. † Discussion on paper read in abstract. ‡ Read before the Commission on Surface Waters. 